\title{
THE MAIN DIRECTIONS OF ECONOMIC COOPERATION BETWEEN UKRAINE AND NATO IN THE $21^{\text {st }}$ CENTURY
}

\author{
Andrii Magomedov ${ }^{1}$
}

\begin{abstract}
The purpose of the article is to show the development process of Ukraine's relations with NATO in the economic sphere, to analyze the main directions and tasks of economic cooperation, to trace the dynamics of their development and dependence on the domestic political situation in Ukraine during recent decades. Methodology. The research is based on the analysis of official electronic sources and reports on the activities and cooperation of NATO countries with the Ukrainian side. The data from the Ministry of Foreign Affairs of Ukraine, the Ministry of Energy of Ukraine and the Ministry of Defence of Ukraine were used. As a result of the research there can be traced a clear pattern of dependence of the implementation of the number of new programs on economic cooperation with the actual vector of foreign policy relations of the highest authorities of Ukraine. Although this vector has changed dramatically over the last twenty years since the election of the new president, the indicators of funding and implementation of the new cooperation programs demonstrate a positive dynamics in Ukraine-NATO relations, especially with the active support of our country's political leadership. Practical implications. As Ukraine has chosen the European path of development, it is important to understand the patterns of economic cooperation both between the countries of the NATO bloc itself and between the Allies. The materials for the analysis of the results of cooperation can serve as a basis for further projects and the development of allied relations. Value/originality. The article opens opportunities for further research and comparison of economic cooperation programs of the other blocs with which Ukraine has cooperated for the last quarter of a century.
\end{abstract}

Key words: NATO, Ukraine, economic cooperation, European course.

JEL Classification: F02, F52, F52, F55

\section{Introduction}

As NATO's core business is security and defence, an important role in Ukraine-Alliance relations is played by the work in the sphere of economics that is focused on the specific economic aspects of security and defence. In addition, the Alliance always supports cooperation between its members when it comes to economic issues that have a direct impact on security and defence (Spivrobitnytstvo Ukraina - NATO u sferi ekonomiky).

Ukraine's cooperation with NATO in the field of economic aspects of defence and security under the auspices of the NATO-Ukraine Joint Working Group on Economic Security (JWG) is carried out in two directions: 1) institutional dialogue focusing on economic issues of defence and security and economic aspects of defence industry restructuring; 2) retraining activities for servicemen discharged to reserve (Spivrobitnytstvo
Ukraina - NATO, 2018). Thus, within the framework of the Charter on a Distinctive Partnership, an Agreement was concluded on October 11, 1999 between the National Coordination Center for Social and Professional Adaptation of Discharged or Retired Servicemen (NCC), the Cabinet of Ministers of Ukraine and NATO "On the Practical Implementation of the NATO Initiative on retraining of Ukrainian servicemen discharged to reserve or resignation" (Avtushenko, 2018: 102-103). As a result, the NATO Office of Economic Security and Defence has launched a language training program for exservicemen in Ukraine. Since 1999, the British Council in Ukraine and NATO have jointly developed the program under which the British Council has implemented English language courses (Prohrama NATO z perepidhotovky...). However, in total, during 1999-2002, more than 300 officers

Corresponding author:

${ }^{1}$ Hryhorii Skovoroda University in Pereiaslav, Ukraine.

E-mail: magomedovandriy@gmail.com

ORCID: https: //orcid.org/0000-0001-5919-2340

ResearcherID: https://publons.com/researcher/4107344/andriy-magomedov/ 
were retrained in language courses under the NCCNATO Treaty (Avtushenko, 2018: 103; Ukrainski viiskovi..., 2000).

\section{Economic cooperation between Ukraine and NATO under President L. Kuchma}

Socio-political transformations that took place in Ukraine from 2001 to 2005 caused temporary obstacles in the development of new promising economic projects. However, it should be noted that at the NATO Summit in Prague in November 2002, the NATO-Ukraine Action Plan was approved, in which it was identified 12 points of cooperation in the economic field (Plan dii Ukraina-NATO, 2002). Among them there are promoting the restructuring of the economy, economic cooperation between Ukraine, NATO and Partner countries; implementation of the moratorium on the initiation of tax credit bill and the creation of an institutional environment that will stimulate business activity, the creation of modern social infrastructure and mechanisms of social market economy while maintaining an adequate social protection network; carrying out economic and structural reforms, taking into account the recommendations of the World Bank, the International Monetary Fund and other international institutions, including measures to promote privatization, fight corruption and increase the transparency of public spending; expanding the land reform process; guaranteeing of economic rights and freedoms of citizens in all forms; creating the necessary preconditions for the middle class formation; limiting the real income gap between high- and low-income groups and making efforts to eradicate poverty; strengthening of energy security (Malyk, 2014).

These economic objectives of cooperation with NATO were confirmed by the NATO-Ukraine Target Plan for 2003 and 2004. In particular, they provided for an expanded timetable for the activities declared at the 2002 Prague Summit (Pro skhvalennia Planu dii Ukraina, 2003; Pro proekt Tsilovoho planu Ukraina ..., 2003).

\section{Economic cooperation between Ukraine and NATO under President V. Yushchenko}

The situation in economic relations changed to some extent only in April 2005, when President Yushchenko consolidated Ukraine's EuroAtlantic course by signing on April 21 a document on "Deepening Ukraine-NATO Cooperation: Short-Term Measures". NATO members and Ukraine then agreed to launch new initiatives to deepen their cooperation in support of Ukraine's reform priorities. In particular, the parties agreed to expand assistance in addressing issues related to the socio-economic consequences of military reform, which provided at the working level to expand the transfer of experience of NATO member states to support urgent work on the development and implementation of retirement programs and retraining of members of the Armed Forces and other security structures, in particular, including: an expert support for needs assessment and development of a comprehensive retraining / requalification; increase of practical assistance for specific retraining programs in 2005 and 2006; a search for means to meet Ukraine's long-term retraining needs. It was also planned to provide expert advice to representatives of the defence industry of Ukraine in order to facilitate its adaptation to new market realities (Pohlyblennia spivpratsi Ukraina ..., 2005).

Already in September 2005, with the assistance of the Alliance, the NATO Trust Fund of the program 'Partnership for Peace' was funded, namely the second stage of the professional development program. The estimated budget of the fund amounted to 574 thousand EUR (Diiuchi proekty Trastovykh fondiv NATO...). This project became a logical continuation in Ukraine of the program launched by the United Kingdom in 2002. For this purpose, in 2006 the Khmelnytskyi Center for Retraining and Social Adaptation was established at Khmelnytskyi National University ( $\mathrm{Na}$ try roky prolonhovano..., 2009). Retraining was carried out on 3-month courses conducted on a 500-hour program.

In 2007, Ukraine joined another NATO Trust Fund - Integrity Development Program (ID). NATO member states have decided to launch this fund to enhance integrity, transparency, accountability and appropriate governance in the security and defence sector (Dopomoha trastovykh fondiv NATO Ukraini, 2016). Also since 2007, the issues of energy security and security of energy infrastructure have been included to the agenda of the meetings of the Associated Working Group (AWG) on economic security. And since 2008, within the framework of the NATO-Ukraine AWG, the project to combat terrorist financing and 
prevent money laundering has been implemented (Spivrobitnytstvo Ukraina - NATO, 2018).

At the same time, it was continued the work on retraining ex-servicemen within the framework of NATO Professional Development Program Trust Fund. In particular, according to the NATO civilian budget during 2007-2008, regional retraining courses for servicemen were established in Lviv, in the village Ozerne, Zhytomyr region, Mukacheve, Zakarpattia region, Ternopil and Slavuta, Khmelnytskyi region, etc. (Na try roky prolonhovano..., 2009), at which about 1,500 servicemen had been retrained by 2009 (Avtushenko, 2014: 202).

Since 2009, the network of retraining centers for ex-servicemen has expanded in Ukraine. Thus, the Trust Fund has expanded its activities to Kharkiv region (the leading country was Denmark) (18 chervnia 2013 ..., 2013), Mykolaiv (Perepidhotovka viiskovosluzhbovtsiv) etc.

\section{Economic cooperation between Ukraine and NATO under President V. Yanukovych}

Another step in Ukraine's cooperation with NATO was the establishment in 2011 of the Disposal of Radioactive Waste Trust Fund project with a budget of 950 thousand EUR, which aims to safely store radioactive waste generated as a result of military programs of the Armed Forces of the USSR in Zhytomyr region (Dopomoha trastovykh fondiv NATO Ukraini, 2006).

OnJune 18,2013, a solemn graduation ceremony was held for the twelfth stage of professional training of servicemen and retraining groups of former servicemen in Chuhuiv, who were trained at the Interdisciplinary Institute of Postgraduate Education of the National Technical University "Kharkiv Polytechnic Institute'. 47 people were retrained (18 chervnia 2013 ..., 2013). And in December 2013, the solemn graduation ceremony of Khmelnytskyi Center for Retraining and Social Adaptation at Khmelnytskyi National University took place, as well as the official closing of the NATO Partnership for Peace Trust Fund. 116 graduates received certificates of professional development. Their training was $78 \%$ funded by the NATO Partnership for Peace Trust Fund and $22 \%$ by the NATO Civilian Budget. In total, since 2006, by Khmelnytskyi Center it has been organized retraining of 2,129 people and provided assistance to 1,067 former servicemen employed in the civil sector of the economy (U Khmelnytskomu tsentri perepidhotovky..., 2013).

\section{Economic cooperation between Ukraine and NATO after the beginning of the Ukraine-Russia conflict}

In response to Russia's aggressive actions against Ukraine, NATO members decided at the Welsh Summit in September 2014 to establish five new trust funds (TF) to assist Ukraine in critical areas (NATO stvoriuie piat trastovykh fondiv..., 2014). The funds were established in the following areas: Command, Control, Communication and Computerization (C4); Logistics and Standardization; Cyber Defence; Military Career Transition; Medical Rehabilitation. In addition, at the request of Ukraine, in June 2015, the Alliance agreed to launch the sixth Trust Fund - for Counter-Improvised Explosive Devices and Explosive Ordnance Disposal (Analiz oboronno-tekhnichnoho..., 2016: 82-85; Dopomoha trastovykh fondiv NATO Ukraini..., 2016). The estimated total budget of NATO's trust fund projects in Ukraine has grown to almost 40 million EUR since its inception. The largest funding is provided under the old program for the disposal of antipersonnel mines, obsolete and surplus stockpiles of weapons and ammunition. The leading sponsor of the program is the United States. The total budget for its assistance is 25 million EUR (Trastovi fondy NATO v Ukraini: ..., 2017). The funds are also used to retrain the Ukrainian military, establish a communication system, treat the wounded, reform logistics systems and implement NATO standards in the Armed Forces of Ukraine, etc. (Priorytety trastovykh fondiv NATO..., 2014). And within the framework of TF for Medical Rehabilitation in medical institutions of NATO countries from 2014 to 2018, prosthetics of 11 ATO participants were provided, medical rehabilitation of 280 people and vocational rehabilitation of 13 more servicemen were provided. As part of the active rehabilitation program 'Return to Life', 125 servicemen were rehabilitated. In addition, financial support was provided to the national team of Ukraine in the international competition "Invictus Games" (NATO dopomahaie Ukraini stvoryty..., 2018). In total, six Ukrainian medical rehabilitation institutions are supported within this TF, they are provided with modern equipment (Aleksander Vinnikov...). It should be noted that NATO member states increase their contributions 
to a number of trust funds (TF) from time to time to support Ukraine. In particular, it is the question of TF on disarmament, burial of radioactive waste and medical rehabilitation of the servicemen wounded in anti-terrorist operation (ATO), etc. (NATO posylyt pidtrymku ..., 2019).

\section{Findings}

Firstly, from the above data it is possible to clearly see how the number of joint economic programs to support Ukraine changed, depending on the vector of foreign policy relations of the ruling elite. How rapidly the number of economic cooperation programs and the total amount of their funding during

V. Yushchenko's presidency increased, how diametrically opposite was the effect during the presidency of V. Yanukovych. And as it is known now, these steps were aimed at the direct destruction of Ukraine's defence capabilities, and were carried out under the watchful leadership of the Russian Federation. The above information can serve as a basis for further analysis of foreign policy relations between Ukraine and military blocs and be used to substantiate the European vector of Ukraine's foreign policy relations.

\section{Conclusions}

The establishment of five new trust funds in 2014 and the intensive deepening of Ukraine's cooperation with NATO to some extent have changed the work of NATO Information and Documentation Centre (NIDC) in Ukraine. The center has gained two additional tasks: 1) to provide information on NATO's practical support for Ukraine, for example, through eight trust funds totaling 40 million EUR, in areas such as medical rehabilitation, command and control or logistics, and also through advisory support to the Armed Forces of Ukraine in their reforms; 2) support to the Ukrainian government in enhancing its communication capabilities in the field of strategic and crisis communications. The ability of Ukrainian institutions to effectively communicate to the domestic and foreign audience information about events in Ukraine, in particular about the events in the East and the course of reforms, is very important (Stepaniuk, 2020). These changes at NIDC were only the beginning of a new institutional consolidation of cooperation between Ukraine and NATO. After all, in September 2015, the NATO General Secretary signed an Agreement with the Government of Ukraine, according to which a NATO Delegation was established in Ukraine, which included two NATO institutions in Ukraine, namely: the NATO Information and Documentation Center and the NATO Liaison Office in Ukraine (Tsentr informatsii ta dokumentatsii..., 2017).

\section{References:}

18 chervnia 2013 roku vidbudetsia urochysta tseremoniia vypusku hrup dvanadtsiatoho etapu profesiinoho navchannia viiskovosluzhbovtsiv (2013) [On June 18, 2013, a solemn graduation ceremony of the groups of the twelfth stage of servicemen' professional training will take place]. Available at: https:/\%cutt.ly/7kteYLs

Avtushenko, I. (2014). Mizhnarodni prohramy sotsialno-profesiinoi adaptatsii zvilnenykh viiskovosluzhbovtsiv Zbroinykh Syl Ukrainy ta chleniv yikh simei [International programs of social and professional adaptation of discharged servicemen of the Armed Forces of Ukraine and members of their families]. Etnichna istoriia narodiv Yevropy [Ethnic history of the peoples of Europe], vol. 42, pp. 201-206. Avtushenko, I. (2018). Perepidhotovka viiskovosluzhbovtsiv zbroinykh syl Ukrainy za prohramoiu NATO-Ukraina [Retraining of servicemen of the Armed Forces of Ukraine under the NATO-Ukraine program]. Yevropeiski istorychni studii [European historical studies], vol. 11, pp. 99-112.

Aleksander Vinnikov, hlava Predstavnytstva NATO v Ukraini: «Soiuznyky khochut, shchob Ukraina stala istoriieiu uspikhu» [Alexander Vinnikov, Head of NATO Delegation to Ukraine: «Allies want Ukraine to be a success story»]. Ministerstvo oborony Ukrainy. Novyny [Ministry of Defence of Ukraine. News]. Available at: https://www.mil.gov.ua/special/news.html?article=34745 (accessed 11 August 2020).

Diiuchi proekty Trastovykh fondiv NATO v Ukraini [Current projects of NATO Trust Funds in Ukraine]. Tsentr mizhnarodnoi bezpeky ta partnerstva [Center for International Security and Partnership]. Available at: http://www.ispc.org.ua/archives/3965 (accessed 11 August 2020).

Dopomoha trastovykh fondiv NATO Ukraini (2016) [Assistance from NATO Trust Funds to Ukraine]. November 4. Comments \& Policy Briefs (UKR), Conference Papers [November 4. Comments \& Policy 
Briefs (UKR), Conference Papers]. Available at: http://eesri.org/2016/11/nato-trust-funds-assistanceto-ukraine ukr/

Malyk, Ya. (2014). Do pytannia pro yevroatlantychnu intehratsiiu Ukrainy [On the issue of Ukraine's Euro-Atlantic integration]. Naukovyi visnyk «Demokratychne vriaduvannia» [Scientific Bulletin «Democratic Governance»], vol. 14. Available at: http://lvivacademy.com/vidavnitstvo_1/visnyk14/ fail/malyk.pdf (accessed 11 August 2020).

$\mathrm{Na}$ try roky prolonhovano diialnist trastovoho tsentru perepidhotovky kolyshnikh ukrainskykh viiskovykh koshtom NATO u Khmelnytskomu (2009) [The activity of the trust center for retraining of former Ukrainian servicemen at the expense of NATO in Khmelnytskyi was extended for three years]. Ukrinform. Available at: https://www.ukrinform.ua/rubric-regions/785111-na tri roki prolongovano_dyalnst_trastovogo_tsentru_perepdgotovki_kolishnh_ukranskih_vyskovih_koshtom_ nato_u_hmelnitskomu_803203.html (accessed 11 August $2 \overline{0} 20)$.

NATO dopomahaie Ukraini stvoryty kiberpolihon ZSU (2018) [NATO helps Ukraine to create a cyber range of the Armed Forces]. UNIAN. Available at: https://www.unian.ua/politics/10137197-natodopomagaye-ukrajini-stvoriti-kiberpoligon-zsu.html (accessed 11 August 2020).

NATO posylyt pidtrymku Ukrainy v ramkakh trastovykh fondiv (2019) [NATO will strengthen its support for Ukraine through trust funds]. Mind.ua, TOV «Fiucher Media». Available at: https://mind.ua/ news/20196491-nato-posilit-pidtrimku-ukrayini-v-ramkah-trastovih-fondiv (accessed 11 August 2020).

NATO stvoriuie p'iat trastovykh fondiv dlia pidtrymky Ukrainy - Stoltenberh (2014) [NATO is setting up five trust funds to support Ukraine - Stoltenberg]. Hromadske telebachennia. Available at: https://hromadske.ua/posts/nato-stvoriuie-piat-trastovykh-fondiv-dlia-pidtrymky-ukrainy-stoltenberh (accessed 11 August 2020).

Perepidhotovka viiskovosluzhbovtsiv u Chornomorskomu natsionalnomu universyteti imeni Petra Mohyly prodovzhuietsia! [Retraining of servicemen at Petro Mohyla Black Sea National University continues!]. Sait universytetu. Viddil zv'iazkiv iz hromadskistiu ChDU imeni Petra Mohyly [University website. Public Relations Department of Petro Mohyla BSCU]. Available at: https://chmnu.edu.ua/ perepidgotovka-vijskovosluzhbovtsiv/

Plan dii Ukraina-NATO (2002) [NATO-Ukraine Action Plan]. Orhanizatsiia Pivnichnoatlantychnoho dohovoru [Organization of the North Atlantic Treaty]. Ofits. sait. Available at: https://www.nato.int/ cps/uk/natohq/official_texts_19547.htm?selectedLocale=uk (accessed 11 August 2020).

Pohlyblennia spivpratsi Ukraina - NATO: korotkoterminovi zakhody (2005) [Deepening NATOUkraine cooperation: short-term measures]. Skhvaleno na zasidanni Komisii Ukraina - NATO na rivni ministriv zakordonnykh sprav [Approved at a meeting of the NATO-Ukraine Commission at the level of foreign ministers]. Vilnius. Available at: https://zakon.rada.gov.ua/laws/show/950_012\#Text (accessed 11 August 2020).

Priorytety trastovykh fondiv NATO z pidtrymky Ukrainy - infohrafika (2014) [Priorities of NATO Trust Funds in Support of Ukraine - Infographics]. Yevropeiska pravda. Available at: https://www.eurointegration.com.ua/news/2014/12/24/7029138/ (accessed 11 August 2020).

Pro proekt Tsilovoho planu Ukraina - NATO na 2004 rik (2003) [About the draft NATO-Ukraine Target Plan for 2004]. Derzhavna rada z pytan yevropeiskoi i yevroatlantychnoi intehratsii Ukrainy [State Council for European and Euro-Atlantic Integration of Ukraine]. Available at: https://zakon.rada.gov.ua/rada/ show/v0004520-03\#Text (accessed 11 August 2020).

Pro skhvalennia Planu dii Ukraina - NATO ta zatverdzhennia Tsilovoho planu Ukraina - NATO na 2003 rik (2003) [On approval of the NATO-Ukraine Action Plan and approval of the NATO-Ukraine Target Plan for 2003]. Derzhavna rada z pytan yevropeiskoi i yevroatlantychnoi intehratsii Ukrainy [State Council for European and Euro-Atlantic Integration of Ukraine]. Available at: http://search.ligazakon.ua/1_doc2. nsf/link1/MUS1325.html (accessed 11 August 2020).

Prohrama NATO z perepidhotovky - kursy anhliiskoi movy dlia kolyshnikh viiskovosluzhbovtsiv [NATO's retraining program - English language courses for ex-servicemen]. Ofits. storinka. Brytanska Rada v Ukraini [Officer. page. British Council in Ukraine]. Available at: https://www.britishcouncil.org.ua/ NATO-english-courses (accessed 11 August 2020).

Spivrobitnytstvo Ukraina - NATO (2018) [Ukraine-NATO Cooperation]. Ministerstvo enerhetyky Ukrainy. Ofits. sait [Ministry of Energy of Ukraine. Officer. site]. Available at: http://mpe.kmu.gov.ua/ minugol/control/uk/publish/article?art_id=245272302\&cat_id=162068 (accessed 11 August 2020).

Spivrobitnytstvo Ukraina - NATO u sferi ekonomiky [NATO-Ukkraine economic cooperation]. Ofits. sait Ministerstva zakordonnykh sprav Ukrainy [Officer. website of the Ministry of Foreign Affairs of Ukraine]. Available at: https://ukraine-nato.mfa.gov.ua/ukrayina-nato/spivrobitnictvo-ukrayina-nato-u-sferiekonomiki (accessed 16 August 2020). 
Stepaniuk, O. (2020). Tsentru informatsii ta dokumentatsii NATO v Ukraini vzhe 23 roky [The NATO Information and Documentation Center in Ukraine has been operating for 23 years]. «ArmiiaInform». Available at: https://armyinform.com.ua/2020/05/czentru-informacziyi-ta-dokumentacziyi-nato-vukrayini-vzhe-23-roky/ (accessed 11 August 2020).

Trastovi fondy NATO v Ukraini: ne miliardy, a miliony (2017) [NATO trust funds in Ukraine: not billions, but millions]. VSS Ukraina. Available at: https://www.bbc.com/ukrainian/news-40276214 (accessed 11 August 2020).

U Khmelnytskomu tsentri perepidhotovky ta sotsialnoi adaptatsii vidbuvsia vypusk slukhachiv (2013) [Students graduated from the Khmelnytsky Center for Retraining and Social Adaptation]. Ofits. sait Ministerstva oborony [Officer. website of the Ministry of Defense]. Available at: https://www.mil.gov.ua/ news/2013/12/10/u-hmelniczkomu-czentri-perepidgotovki-ta-soczialnoi-adaptaczii-vidbuvsyavipusk-sluhachiv/ (accessed 11 August 2020).

Ukrainski viiskovi otrymuiut tsyvilni spetsialnosti (2000) [Ukrainian military receive civilian specialties]. Available at: https://www.ukrinform.ua/rubric-polytics/21694-ukransk_vyskov_otrimuyut_tsivln_ spetsalnost_28856.html (accessed 11 August 2020).

Tsentr informatsii ta dokumentatsii NATO v Ukraini (2017) [NATO Information and Documentation Center in Ukraine]. Orhanizatsiia Pivnichnoatlantychnoho dohovoru. 01 bereznia [Organization of the North Atlantic Treaty, March 1]. Available at: https://www.nato.int/cps/uk/natolive/topics_64610.htm (accessed 11 August 2020).

Shpura, M. I., Andriianova, N. M., \& Komolaieva, T. M. (2016). Analiz oboronno-tekhnichnoho spivrobitnytstva Ukrainy z NATO v ramkakh trastovykh fondiv [Analysis of Ukraine's defense and technical cooperation with NATO within the framework of trust funds]. Zbirnyk naukovykh prats Tsentru voienno-stratehichnykh doslidzhen Natsionalnoho universytetu oborony Ukrainy imeni Ivana Cherniakhovskoho [Collection of scientific works of the Center for Military Strategic Studies of Ivan Chernyakhovskyi National Defense University of Ukraine], vol. 3, pp. 81-86. 